\title{
New names for two Malagasy species of Canarium L. (Burseraceae)
}

\section{Douglas C. Daly, Jeannie Raharimampionona \& Sarah Federman}

\begin{abstract}
DALY, D.C., J. RAHARIMAMPIONONA \& S. FEDERMAN (2016). New names for two Malagasy species of Canarium L. (Burseraceae). Candollea 71: 159-160. In English, English and French abstracts. DOI : http://dx.doi.org/10.15553/c2016v711a19

New names are provided for two recently described Malagasy species of Canarium L. (Burseraceae) for which the epithets proved to be later homonyms of already published taxa. These new names are Canarium fugax Daly, Raharim. \& Federman, and Canarium lobocarpum Daly, Raharim. \& Federman.
\end{abstract}

\section{Résumé}

DALY, D.C., J. RAHARIMAMPIONONA \& S. FEDERMAN (2016). Noms nouveaux pour deux espèces malgaches de Canarium L. (Burseraceae). Candollea 71: 159-160. En anglais, résumés anglais et français. DOI: http://dx.doi.org/10.15553/c2016v711a19

Des noms nouveaux sont proposés pour deux espèces de Canarium L. (Burseraceae) malgaches récemment décrites, dont les épithètes sont des homonymes postérieurs de taxons déjà publiés. Les nouveaux noms sont Canarium fugax Daly, Raharim. \& Federman, and Canarium lobocarpum Daly, Raharim. \& Federman.

\section{Keywords}

BURSERACEAE - Canarium - New names - Madagascar

\footnotetext{
Addresses of the authors:

DCD : New York Botanical Garden, Institute of Systematic Botany, 2900 Southern Blvd., Bronx, NY, 10458-5126, U.S.A. E-mail: ddaly@nybg.org JR: Missouri Botanical Garden, Madagascar Program, P.O. Box 3391 Antananarivo 101, Madagascar. 


\section{Introduction}

The authors recently published a revision of Canarium L. (Burseraceae) in Madagascar (DALY et al., 2015). The genus is at present represented in Madagascar by 33 species, 27 of which were published as new to science in the revision. Oversight on the part of the first author resulted in the application of two previously published names which were then found to be illegitimate later homonyms. Fortunately, both species are exceedingly rare, avoiding the problem of numerous wrongly annotated specimens in various herbaria.

\section{Nomenclature}

Canarium fugax Daly, Raharim. \& Federman, nom. nov.

$\equiv$ Canarium laxiflorum Daly, Raharim. \& Federman in Adansonia ser. 3, 37: 316. 2015 [nom. illeg.] [non C. laxiflorum Decne.].

Typus: Madagascar. Prov. Toamasina: S du Campement de Tampolo, $17^{\circ} 17^{\prime} \mathrm{S} 49^{\circ} 25^{\prime} \mathrm{E}$, 21.X.2001, Rabevohitra, Breteler \& Aridy 3985 (holo- : P [P00501630]!; iso-: TEF!).

Etymology. - The new epithet refers to the species' fugacious stipules and inconspicuous ("shy") inflorescence bracts.

Observations. - Canarium laxiflorum was published by Decaisne in 1834 based on material collected in Timor, but he did not cite specific specimens in his work. There are two specimens from Timor in P [P00337578, P00337579] cited as Riedlé \& Guichenot s.n. by Leenhouts (1959: 391) and designated by him as the neotype and an isoneotype respectively of Amyris oleosa Lam. (= Canarium oleosum (Lam.) Engl.). There is a duplicate specimen in $\mathrm{G}$ [G00236833] also annotated as an isoneotype of $C$. oleosum, but on the same specimen there is also an unattributed annotation as an isotype of $C$. laxiflorum. An on-line search of the BR herbarium did not turn up any of the names involved.

Authorship of C. laxiflorum has alternatively been attributed to "Zipp. ex Blume" published in Blume (1850) in various online databases, e.g.: IPNI (http://www.ipni.org), TROPICOS (http://www.tropicos.org) and SONNERAT (http://science.mnhn.fr/institution/mnhn/collection/p/item/ search/form). In that publication, however, Blume was not publishing C. laxiflorum but rather transferring it to Pimela Lour. Moreover, he made it clear that he was referring to material annotated in the herbarium of Alexander Zippelius (1797-1828) and not the Canarium laxiflorum of Decaisne.

In summary, although the location of the type of C. laxiflorum Decne. is in doubt, the name is taken and C. laxiflorum Daly, Raharim. \& Federman must be treated as a later homonym.
Canarium lobocarpum Daly, Raharim. \& Federman, nom. nov.

$\equiv$ Canarium angulatum Daly, Raharim. \& Federman, Adansonia ser. 3, 37 : 290. 2015 [nom. illeg.] [non C. angulatum Ridl.].

Typus: Madagascar: sine loc., s.d., Cours 4933 (holo- : P [P05311852 sheet 1, P05311856 sheet 2]!).

Etymology. - The new epithet refers to the slightly lobed appearance of the dry fruits in dorsiventral view.

Observations. - Canarium angulatum Ridl. described by RIDLEY in 1931 was treated as a taxonomic synonym of Dacryodes incurvata (Engl.) H. J. Lam by Leenhouts (1959).

\section{Acknowledgments}

We thank Helen Hartley (K) and Marina Rabarimanarivo (MBG-Madagascar), who independently and astutely discovered the later homonyms applied by the senior author.

\section{References}

Blume, C.L. (1850). Ord. Terebinthaceae Subord. Burseraceae. Mus. Bot. $1: 209-224$.

Daly, D.C., J. Raharimampionona \& S. Federman (2015). A revision of Canarium (Burseraceae) in Madagascar. Adansonia ser 3, 37: 277-345.

Leenhouts, P.W. (1959). Revision of the Burseraceae of the Malaysian area in a wider sense. Xa. Canarium Stickm. Blumea 9: 275-475.

Perrier de la Bâthie, H. (1946). Burseracées. In: Humbert, H. (ed.), Fl. Madagascar Comores 106.

Ridley, H.N. (1931). Additions to the flora of Borneo and other Malay islands : III. Bull. Misc. Inform. Kew 1931: 493-499. 